\title{
Methodology of Cyclical Research of the Tourist Image of Podkarpackie Province (Poland)-A Proposal of a Solution and Selected Research Results
}

\author{
Beata Jolanta Gierczak-Korzeniowska ${ }^{1, *}$, Mateusz Stopa ${ }^{2}$ and Krzysztof Szpara ${ }^{3}$ \\ 1 Department of Economics and Management, Institute of Economics and Finance, University of Rzeszow, \\ 35-601 Rzeszow, Poland \\ 2 Department of Media and Social Sciences, University of Stavanger, 4021 Stavanger, Norway; \\ mateusz.b.stopa@uis.no \\ 3 Polish Geographical Society, Rzeszow Branch, 35-030 Rzeszow, Poland; kszpara@o2.pl \\ * Correspondence: bgierczak@ur.edu.pl
}

check for

updates

Citation: Gierczak-Korzeniowska,

B.J.; Stopa, M.; Szpara, K.

Methodology of Cyclical Research of the Tourist Image of Podkarpackie

Province (Poland) —A Proposal of a

Solution and Selected Research

Results. Sustainability 2022, 14, 2673.

https://doi.org/10.3390/su14052673

Academic Editors: Raquel Camprubí and Ariadna Gassiot-Melian

Received: 24 November 2021

Accepted: 21 February 2022

Published: 25 February 2022

Publisher's Note: MDPI stays neutral with regard to jurisdictional claims in published maps and institutional affiliations.

Copyright: (c) 2022 by the authors Licensee MDPI, Basel, Switzerland. This article is an open access article distributed under the terms and conditions of the Creative Commons Attribution (CC BY) license (https:/ / creativecommons.org/licenses/by/ $4.0 /)$.

\begin{abstract}
The attractiveness to tourists of Podkarpackie Province is related to its natural diversity and rich cultural heritage. The communes located in the southern, Carpathian part of the province are the most attractive tourist destinations. However, the volume of tourist traffic in Podkarpackie Province differs from many other regions in Poland. It is visited by far fewer tourists than might be expected. In order to conduct a more effective tourist policy, it was necessary to acquire knowledge on the structure of tourism in the region and its image. The aim of this article is to present the proprietary methodology of cyclical research of the tourist image of Podkarpackie Province and the key results of the research conducted in 2021. The proposed set of methods and techniques includes: (1) an analysis of strategic documents in terms of the assumed tourist image (Atlas.ti), (2) a verification of search trends for keywords related to the identified associations (Google Trends), and (3) a search of widely available internet resources for spontaneously generated content (Google Search). The obtained results indicate that potential tourists find online information about tourist assets deviating from the planned tourist image presented in the strategic document. First of all, they look for opinions and tips on specific tourist attractions. In the perceptions of average, potential tourists, some sub-regions such as the Low Beskids and the Southern Roztocze are practically unnoticeable. They clearly 'lose' with the Bieszczady, which are most associated with the region. Ultimately, the comprehensive image research consists of qualitative and quantitative modules. Only the combination of both will allow for a holistic view of the image of the region.
\end{abstract}

Keywords: methodology; image research; tourist image; tourism; Podkarpackie Province; strategic documents

\section{Introduction}

A positive image of a tourist region affects the behaviour and attitudes of tourists, which translate into the choice of their destination, recommendations and their loyalty to a specific product, such as a region. Therefore, creating both an attractive and distinctive image is a challenge for the management of the region. On the one hand, there is an official image, which is the intention of the local government authorities and which is embodied in the relevant documents. On the other hand, there is also the image of what tourists see and experience and what they share in social media. Eliminating inconsistencies and, above all, discrepancies between those two views is the key to success and a guarantee of gaining an image-related competitive advantage.

The tourist image of Podkarpackie Province, defined as an administrative region, formalised in strategic documents, is primarily the area of management of the local government authorities at the provincial level. It is the Provincial Board, with the approval of 
the Provincial Assembly, which defines the main directions and channels for promoting the tourist value of its region. In other words, the regional community, through its local government representatives, is responsible for whether and how it will take measures to strengthen its own regional tourism sector. This takes the form of specific provisions in official strategic documents-with a specified time horizon, set objectives and indicated tools for achieving those objectives, as well as verification of the adopted assumptions.

Such studies are, therefore, the most formalised manifestation of managing and shaping the tourist image of the region. At the other extreme there are, of course, informal, private and individual opinions and beliefs, which, when made public, especially with the contemporary possibilities of social media, create a spontaneous, impulsive and uncontrolled image of the same area. The current image is the result of these two extreme factors. Using tools such as image strategy, it is possible to set directions and shape opinions as well as highlight the advantages already recognised by potential recipients, while it is also necessary to react to emerging signals of unfulfilled expectations or disappointment. Image management, therefore, resembles sailing, with an objective set at a given moment and an azimuth leading to it, but requiring an ongoing response to the changing winds of public opinion.

These changing winds are primarily the changing preferences and needs of tourists and how they are satisfied. This satisfaction, in turn, translates into the perceived attractiveness of the region or city in the eyes of tourists.

The attractiveness to tourists of Podkarpackie Province is related to its natural diversity and rich cultural heritage. The communes located in the southern Carpathian part of the province-especially in the Bieszczady and the Sanocko-Turczańskie Mountains-are the most attractive tourist destinations, both in the summer and winter seasons.

Podkarpackie Province is known for its unique natural environment. There are the largest lynx, wolf and bear populations in the country, as well as the habitats of many other rare plant and animal species. Particularly valuable areas are under protection, including the Bieszczady National Park, the largest mountain national park in Poland, and the Magura National Park. The most valuable fragments of Carpathian beech forests were inscribed on the UNESCO World Heritage List in 2021. The attractiveness of the area is also influenced by, among others, the varied landscape, especially in the Carpathian part of the province, and a significant forest cover of over 38\%. The Solina Dam - the largest in Poland in terms of volume-is a popular tourist destination. Another important asset of the region is its rich cultural heritage, including the UNESCO World Heritage-listed wooden churches in Blizne and Haczów and the wooden Orthodox churches in Chotyniec, Radruż, Smolnik and Turzańsk. Valuable exhibitions are presented in numerous museums and open-air museums (e.g., the Museum of Folk Architecture in Sanok-one of the largest in Europe, and the Ignacy Łukasiewicz Memorial Museum of Oil and Gas Industry in Bóbrka-the world's oldest oil mine). In addition, the culinary heritage of the region has enormous potential. Based on this potential, different types and forms of tourism are developing, including active, cognitive, spa, religious and business tourism.

Despite its unique qualities, the volume of tourist traffic in Podkarpackie Province lags behind many other regions in Poland. The latest data available is of 2019, before the COVID-19 outbreak. At that time, according to the Central Statistical Office, 3,602,108 overnight stays were recorded in the accommodation capacity, accounting for $3.9 \%$ of overnight stays in the country. This placed Podkarpackie Province ninth among sixteen provinces in Poland. At the same time, 279,053 overnight stays were provided to foreign tourists (1.5\% of overnight stays in the country), which ranked the province at 12 th place. These data show that, despite many interesting and valuable activities aimed at regional promotion conducted by the Podkarpackie Regional Tourist Organisation, as well as other institutions, far fewer tourists visit Podkarpackie Province than would be expected.

In order to conduct a more effective tourist policy, it is necessary to know the volume and structure of tourism and the tourist image of Podkarpackie Province. The data on the volume of tourism are provided by the Central Statistical Office. The statements are 
prepared as a part of standard statistical reporting. The data are not complete, but knowing what kind of errors they are burdened with makes it possible to estimate the missing data. In order to have knowledge on the structure of tourism, the local government of Podkarpackie Province, together with the Podkarpackie Regional Tourist Organisation, decided to renew tourist research, this time on a cyclical basis (At the request of the Marshal's Office of Podkarpackie Province, the first comprehensive research of tourism in Podkarpackie Province was conducted in 2009. At that time, the experience of the research design team in Małopolskie Province was used. Podkarpackie was, then, among the few provinces in Poland where such research was conducted. The research was repeated using a slightly different approach in 2011. It was conducted by SMG/KRC Poland Media S. A., based in Warsaw). The last missing element useful for implementing tourism policy in the region was the research on the image of tourism. In 2020, a methodology for tourist research was developed [1], pilot studies were conducted [2], followed by full studies in 2021 [3]. In 2021, research was conducted on the methodology of that research [4], which, to some extent, was completed in the same year [5]. The full-scale research is to be conducted in subsequent years.

The aim of this article is to present the proprietary methodology, developed for the purposes of cyclical research of the tourist image of Podkarpackie Province (corresponding to the EU NUTS-2 classification). The proposed solution is unique, in the authors' opinion, because it is a mixed methodology solution which the authors have not encountered in any of the known publications on the research of the tourist image of the entire administrative region. It combines both quantitative and qualitative approaches, with a simultaneous focus on strategic documents, the spontaneous opinions of potential tourists and the beliefs and opinions of potential recipients surveyed on a nationwide representative sample.

The presented research results cover only the first stage of the entire complex algorithm of proceedings, designed for a 5-year period. Practical empirical activities are used as evidence for the implementation of the assumptions of the methodology. In this way, the authors wanted to familiarise the reader with the possible results of the applied methodology and to shift the emphasis from the theoretical-methodological to the methodological article.

\section{Literature Review}

\subsection{The Theoretical Framework for the Concept of the Tourist Image}

Invariably over the years, researchers as well as entrepreneurs and, above all, managers and decision makers have been trying to understand how tourists create [6] and perpetuate the image of a tourist destination. Tourist destinations and regions are intangible products, and it is difficult to 'try' them before buying; therefore, the tourist image is a fundamental element of the competitive advantage between destinations and a criterion that potential travellers take into account. Thus, the questions posed by managers and decision makers seem to be justified and understandable, and the knowledge related to tourists' image perception is very important [7].

Image awareness and its perception affects tourism decision-making in the future [8-10], the level of satisfaction and memories [11], and, highly important for the promotion and development of the region, its recommendation to other people [12]. The tourist image creates a local identity [13] and is of key importance in the choice of destination by potential tourists. However, defining the concept of the tourist image of the region becomes problematic, as the very word image gives rise to some difficulties in interpretation due to the number of disciplines or contexts it is sometimes considered in [11].

The word image (Latin 'imago') means 'picture,' 'likeness' or 'perception', which can refer to a person, company or product [14]. An image is also sometimes defined as the sum of beliefs, ideas and impressions which people relate to a place $[15,16]$, but simplified in terms of a large number of associations and pieces of information about a given area [17].

For W. H. Reynolds [18] an image of the place is 'a mental construct developed by the consumer on the basis of many other impressions.' It can also be a set of associations related 
to functional parts of a city, region, people or events during direct or indirect contact [19], as well as a cognitive impression [9], or a feeling [20] accompanying us at that time.

So what is the tourist image of a region or place? The dimension of the image of a tourist destination was first classified by C. Gunn [21]. Mayo [22] and Hunt [23] also contributed to the concept of destination image. On the other hand, Kim and Richardson [24] interpret the image of a tourist destination as the sum of tourists' impressions, their thoughts and feelings about the destination. Grosspietsch [25] adds that the perception of the image of a destination, its evaluation and understanding is not detached from cognition and knowledge about the society, politics, economy, life and culture of a given destination.

It can also be defined in dynamic terms as 'a distinct way of processing and storing multisensory information in working memory' [26] and is multidimensional-an impression about an area consisting of various ideas and concepts, experienced individually or collectively, and including both cognitive elements and those resulting from subjective evaluation [27]. The literature also refers to the concept of shaping the tourist image by R. Govers and F. M. Go [28]. They indicate that, in this process, the following factors are important: planned/designed image, communication, marketing, identity and product. In the case of a tourist destination, it is the result of a thought process referring to the knowledge, feelings, opinions and expectations of tourists.

Thus, the image of a destination is a multidimensional construct [29], including both cognitive and affective aspects [30,31]. The cognitive factor refers to the rational evaluation of features or attributes of the destination [32], while the affective factor refers to tourists reactions to various attributes and features of the destination, their experiences and feelings towards the environment as a whole [33]. Cognitive and affective dimensions can also be interrelated [30]. At the same time, in image creation, the cognitive component precedes the emotional [34], which, in turn, exerts a stronger influence on the final effect —-the overall image $[9,35]$. More recent studies are complemented by one more behavioural/conative component, which is related to the tourist's actual behaviour or intention to revisit the destination and recommend it to their friends or family [36-38].

According to MacInnis and Price [39], the tourist image consists of the overall consumption experience. The buyer's attitude towards a product is influenced by both the pre-purchase product image and the buyer's post-purchase experience [40]. Before the purchase (departure), there is a 'substitute consumption' related to the image of the destination (a priori image), which, when consumed on the spot (in the region) may gain in value and satisfy the tourist. After consumption (return), images can play a reconstructive role (a posteriori image) where the tourist relives the experience through holiday memories and souvenirs $[39,41]$. At the same time, depending on psychological and social factors, each tourist individually (differently) assigns emotionally stimulating functions to product attributes. At the same time, the emotional component exerts the greatest influence on evaluation during and immediately after the consumption. With time, the evaluation of consumption becomes more rational.

The tourist image of the region is one of its most important intangible resources and a significant tool of market influence. In the era of competition and dynamic changes in the environment, it gives an opportunity to build a competitive advantage based on resources that are difficult to copy, including knowledge and relational capital. However, it should be remembered that the image is not static and the emphasis is very often put on its processuality and changeability. This is why image research plays such an important role. Therefore, a study on the methodology of researching the image of a tourist destination should take into account the opinions of all parties involved in its creation, including managers, decision makers and researchers, but, above all, tourists and potential visitors. Therefore, this publication assumes that the tourist image of the region is created as a result of the clash of concepts and solutions of decision makers, supported by strategic documents, with the needs and opinions of tourists, as well as all potential interested visitors. 


\subsection{Solutions Used in Research of Tourist Image}

Research into the image of a tourist destination was first proposed by the American scholar Gunn in the 1970s [21] and, since then, has become increasingly important [42]. Its universality was influenced by the development of international tourism, a wider range of tourist products [43] and their homogenisation, as well as the increase in interregional competition. However, despite the importance of research for perception and image building, it is not the most frequently undertaken research.

One of the basic problems of research into the image of a tourist destination is the need to look at a given place or region in a holistic manner [11] along with all its attributes. Therefore, in the research, it is important to include the opinions of all parties that determine the image of the destination, and those for whom the given destination was or may be the future destination, e.g., tourists. It is also important to note that many of the attributes and elements that are taken into account when tourists evaluate the destination are difficult to 'measure,' including the weather or atmosphere. Another problem concerns the issue of the selection of respondents for the research. Will they be people who have never visited a given place, but may have an idea about it from various sources (friends, media, advertising), or only those who create an image and make an evaluation of the place on the basis of their own experiences [44]? The subject under assessment is not insignificant for the nature and difficulty of image research, namely whether it is a city, a small town, a country or a province (region). Research into the image of a province as a region is undertaken much less frequently. The province, as an administrative unit, is located within certain boundaries, which are not identical with tourist attractions or cultural phenomena identified on its territory. The size of the province also influences the multitude of facilities, attractions, cities or the nature of the infrastructure, which affect the perception of all the evaluators. The failures of image research are also related to the methods used to define the image [44].

At the beginning, research on the image of tourist destinations mainly used a questionnaire, often directly interviewing tourists [45]. However, with the development and use of the internet, both the way in which opinions and views are expressed and the possibility for obtaining them changed. Travel journals and online commentaries, reflecting the perception of tourist destinations by tourists, have gained in popularity [46,47]. Hence, in recent years, research that uses social media has received considerable attention (e.g., [48,49]). The explosion of user-generated content, in parallel with the spectacular growth of social media and the proliferation of mobile devices, is causing a paradigm shift in research. Surveys or interviews are no longer necessary to obtain user feedback, as researchers can extract information from social media [50]. For example, Choi et al. [51] assessed Macao's image as a tourist destination by analysing content from Macao's official tourism websites and travel agency websites. Table 1 presents examples of solutions used in the tourism image research (Table 1).

All the above-mentioned methods are effective and enable the understanding of consumers' attitudes, motivations and behaviours, but they lack the holistic approach to tourist image research mentioned earlier. This involves, namely, taking into consideration in the research not only the opinions and perceptions of the 'demand sphere,' but also the 'supply sphere', which consists of all the parties involved in the province (region), and the leading strategic documents. Therefore, it is worth mentioning the research addressing the discrepancy between the projected, intended image (e.g., on the initiative of the local government authorities) and the image of the region as perceived and received by tourists [52,53]. Failure to properly identify and understand the discrepancy between the two views can not only cause misunderstanding among tourists, but also the misuse of resources in image building [29]. In an attempt to fill this gap, we developed a methodology for cyclical research on the tourist image of Podkarpackie Province, which, in its assumption, combines quantitative and qualitative methods. Importantly, it enables the confrontation of many concepts and views (of managers, tourists and potential tourists), verification of the existing assumptions (strategic documents for the province), as well as the creation of such 
an algorithm of conduct that will allow for ongoing monitoring of changes in the image of the province and, consequently, the necessary response.

Table 1. Examples of solutions used in research of tourist image. Source: authors based on [13,50,54-56].

\begin{tabular}{|c|c|c|c|c|}
\hline $\begin{array}{l}\text { What Was Researched } \\
\text { (City, Area, } \\
\text { Region, Country) }\end{array}$ & $\begin{array}{c}\text { Method, Mode of } \\
\text { Analysis }\end{array}$ & $\begin{array}{l}\text { Advantages of } \\
\text { the Research }\end{array}$ & Research Limitations & References \\
\hline $\begin{array}{l}\text { Attica-the historical } \\
\text { region of Greece that } \\
\text { covers the entire } \\
\text { agglomeration of } \\
\text { Athens. }\end{array}$ & $\begin{array}{l}\text { Keyword analysis (textual and } \\
\text { paratextual elements) } \\
\text { contained on the pages. } \\
\text { (TripAdvisor is selected as the } \\
\text { most relevant website). } \\
\text { A random sample of } 300,000 \\
\text { TripAdvisor OTRs (online } \\
\text { travel reviews) on attractions, } \\
\text { activities, restaurants and } \\
\text { hotels written in English } \\
\text { between } 2013 \text { and } 2018 . \text { The } \\
\text { representativeness of the } \\
\text { sample varies in each case } \\
\text { (75\% of attractions, } 95 \% \text { of } \\
\text { hotels and } 60 \% \text { of restaurants). }\end{array}$ & $\begin{array}{l}\text { - A large amount of data. } \\
\text { - The use of modern online } \\
\text { platforms. }\end{array}$ & $\begin{array}{l}\text { - Tourist attractions and } \\
\text { restaurants can be divided } \\
\text { into several categories. } \\
\text { - It is useful to compare } \\
\text { TripAdvisor data (by } \\
\text { contrast) with other online } \\
\text { platforms (e.g., Booking, } \\
\text { Expedia, Yelp or Airbnb), } \\
\text { especially in the } \\
\text { accommodation sector. }\end{array}$ & $\begin{array}{l}\text { Marine-Roig E., } \\
\text { Destination Image } \\
\text { Analytics Through } \\
\text { Traveller-Generated } \\
\text { Content, } 2019 \text { [46] }\end{array}$ \\
\hline the Azores & $\begin{array}{l}\text { A survey questionnaire was } \\
\text { used which included four } \\
\text { closed questions to classify the } \\
\text { general image of the Azores, } \\
\text { as well as to determine their } \\
\text { level of satisfaction with the } \\
\text { archipelago and their } \\
\text { likelihood of recommending } \\
\text { and returning to the Azores. } \\
\text { The questionnaire also } \\
\text { contained a group of questions } \\
\text { on sociodemographic features } \\
\text { (i.e., gender, age, marital } \\
\text { status, education, country of } \\
\text { residence and gross monthly } \\
\text { income). A five-point Likert } \\
\text { scale was used to measure the } \\
\text { overall image of the } \\
\text { destination. The data obtained } \\
\text { were analysed with IBM SPSS } \\
\text { Statistics. Version } 23.0 \text {. The } \\
\text { respondents were tourists } \\
\text { (384 people) divided by } \\
\text { country of residence who } \\
\text { visited the island of São } \\
\text { Miguel (the margin error } \\
\text { of } 5 \% \text { ) }\end{array}$ & $\begin{array}{l}\text { The research also } \\
\text { examined the issue of } \\
\text { satisfaction and the level } \\
\text { of satisfaction with the } \\
\text { archipelago and the } \\
\text { likelihood of returning or } \\
\text { recommending the place. }\end{array}$ & $\begin{array}{l}\text { - The Azores archipelago } \\
\text { consists of nine islands } \\
\text { and this research was } \\
\text { conducted on only one of } \\
\text { them. } \\
\text {-The research measured } \\
\text { tourist satisfaction with a } \\
\text { single questionnaire, } \\
\text { while a multi-scale } \\
\text { measure would have been } \\
\text { more appropriate. } \\
\text {-This was a short-term } \\
\text { study, and therefore, it is } \\
\text { difficult to show changes } \\
\text { in image perception and } \\
\text { consumer behaviour. }\end{array}$ & $\begin{array}{c}\text { Melo H. M., Moniz A. I., } \\
\text { Silva F. J. F., Batista M. } \\
\text { da G., Tourist } \\
\text { Destination image and } \\
\text { consumer behaviour: } \\
\text { The case of The Azores, } \\
\text { Journal of Spatial and } \\
\text { Organizational } \\
\text { Dynamics, } 2017 \text { [47] }\end{array}$ \\
\hline Bangladesh & $\begin{array}{l}\text { Primary research supported by } \\
\text { secondary research. Secondary } \\
\text { research involved the use of } \\
\text { academic journals and reports } \\
\text { from Bangladeshi government } \\
\text { organisations. The } \\
\text { questionnaire; } \\
110 \text { questionnaires distributed } \\
\text { at various locations in } \\
\text { Sheffield in the UK (including } \\
72 \text { fully completed). }\end{array}$ & $\begin{array}{l}\text { - Paying attention to } \\
\text { records in government } \\
\text { documents and } \\
\text { contrasting them with the } \\
\text { views of 'Western } \\
\text { tourists.' }\end{array}$ & $\begin{array}{l}\text { The sample size and } \\
\text { respondent group limited } \\
\text { to only the British. }\end{array}$ & $\begin{array}{c}\text { Zahra I., Destination } \\
\text { image and tourism: A } \\
\text { case study of } \\
\text { Bangladesh, European } \\
\text { Journal of Business and } \\
\text { Management, } 2012 \text { [48] }\end{array}$ \\
\hline
\end{tabular}


Table 1. Cont.

\begin{tabular}{|c|c|c|c|c|}
\hline $\begin{array}{c}\text { What Was Researched } \\
\text { (City, Area, } \\
\text { Region, Country) }\end{array}$ & $\begin{array}{c}\text { Method, Mode of } \\
\text { Analysis }\end{array}$ & $\begin{array}{l}\text { Advantages of } \\
\text { the Research }\end{array}$ & Research Limitations & References \\
\hline North Korea & $\begin{array}{l}\text { Text mining and semantic } \\
\text { network analysis. } \\
\text { Text data in Chinese over the } \\
\text { past } 20 \text { years were collected. } \\
\text { The } 7 \text { most popular travel } \\
\text { websites were used. People } \\
\text { who travelled to North Korea } \\
\text { were investigated. The } \\
\text { frequency of words in two } \\
\text { time periods was considered } \\
\text { (2000-2013 and 2014-2019). }\end{array}$ & $\begin{array}{l}\text { - The content of the } \\
\text { comments included } \\
\text { objective facts, subjective } \\
\text { evaluation, and emotions, } \\
\text { which makes it possible to } \\
\text { understand the perception } \\
\text { of Chinese tourists of } \\
\text { North Korea from various } \\
\text { perspectives. } \\
\text { - A total of } 1155 \text { comments } \\
\text { were included in the } \\
\text { analysis ( } 406 \text { comments } \\
\text { from } 2000 \text { to } 2013 \text { and } \\
749 \text { comments from } 2014 \\
\text { to 2019) }\end{array}$ & $\begin{array}{l}\text { - An analysis of comments } \\
\text { of only those tourists who } \\
\text { visited North Korea } \\
\text { - The research concerned } \\
\text { people from China (similar } \\
\text { culture), no research } \\
\text { among foreign tourists }\end{array}$ & $\begin{array}{l}\text { Li, R.; Wang, H.; Zhang, } \\
\text { H. Chinese Tourists' } \\
\text { Perception of the } \\
\text { Tourism Image of North } \\
\text { Korea Based on Text } \\
\text { Data from Tourism } \\
\text { Websites, 2021 }\end{array}$ \\
\hline Chile and Mexico & $\begin{array}{c}\text { A non-probabilistic } \\
\text { convenience sample was used. } \\
\text { An online questionnaire was } \\
\text { applied and } 1812 \text { valid } \\
\text { answers were obtained ( } 899 \text { in } \\
\text { Chile and } 913 \text { in Mexico). To } \\
\text { avoid seasonal variations, data } \\
\text { collection was conducted over } \\
\text { the entire } 12 \text { months. } \\
\text { Data analysis was performed } \\
\text { using the statistical package } \\
\text { IBM SPSS 25.0. }\end{array}$ & $\begin{array}{c}\text { - International research } \\
\text { (tourists from different } \\
\text { countries), } \\
\text { - The questionnaire was } \\
\text { refined to accurately } \\
\text { reflect Spanish language } \\
\text { idioms, } \\
\text { - Standardisation of } \\
\text { questions and surveys } \\
\text { conducted throughout the } \\
\text { year, } \\
\text { - Country image, country } \\
\text { reputation, country } \\
\text { awareness and visitors }\end{array}$ & $\begin{array}{l}\text { - Failure to consider social } \\
\text { media as a place where } \\
\text { tourists, when creating an } \\
\text { image, combine } \\
\text { knowledge of the country } \\
\text { with its reputation and } \\
\text { visitor satisfaction, } \\
\text { - Low participation of } \\
\text { respondents from } \\
\text { 'non-American' regions }\end{array}$ & $\begin{array}{c}\text { Marinao-Artigas, E.; } \\
\text { Barajas-Portas, K. A } \\
\text { Cross-Destination } \\
\text { Analysis of Country } \\
\text { Image: A Key Factor of } \\
\text { Tourism Marketing, } \\
2021\end{array}$ \\
\hline
\end{tabular}

In summary, image research provides information about the expectations, needs and preferences of many categories of recipients, indicating the direction of further action. Information obtained through image research may constitute a summary which mitigates frequent conflicts [57] between individual entrepreneurs and local government policy. Considering the widespread 'medialisation' of regions, which is a response to the increasingly emerging demand of regions for more efficient and effective methods of image creation [58], it seems reasonable to use the results of image research to build an appropriate message conveyed by the media. Finally, image research itself is a manifestation of creativity and involvement of the entities commissioning it. The results - regardless of expectations provide an irrefutable argument in the discussion of the effectiveness and legitimacy of financing individual activities.

\section{An Innovative Project on the Methodology of Cyclical Research on the Image of the Tourist Region and a Discussion}

The project of the methodology of cyclical research into the tourist image of Podkarpackie Province, presented in this article, is an attempt to respond to the basic challenge of defining the image, with the pragmatic use of the widest possible range of methodological solutions. The presented algorithm of particular stages of activities reflects the outlined dichotomy-the institutionalized and strategy-managed image versus spontaneous, impulsive individual opinions, with regular evaluation of the current popular beliefs about the tourist assets of Podkarpackie Province (Figure 1). 


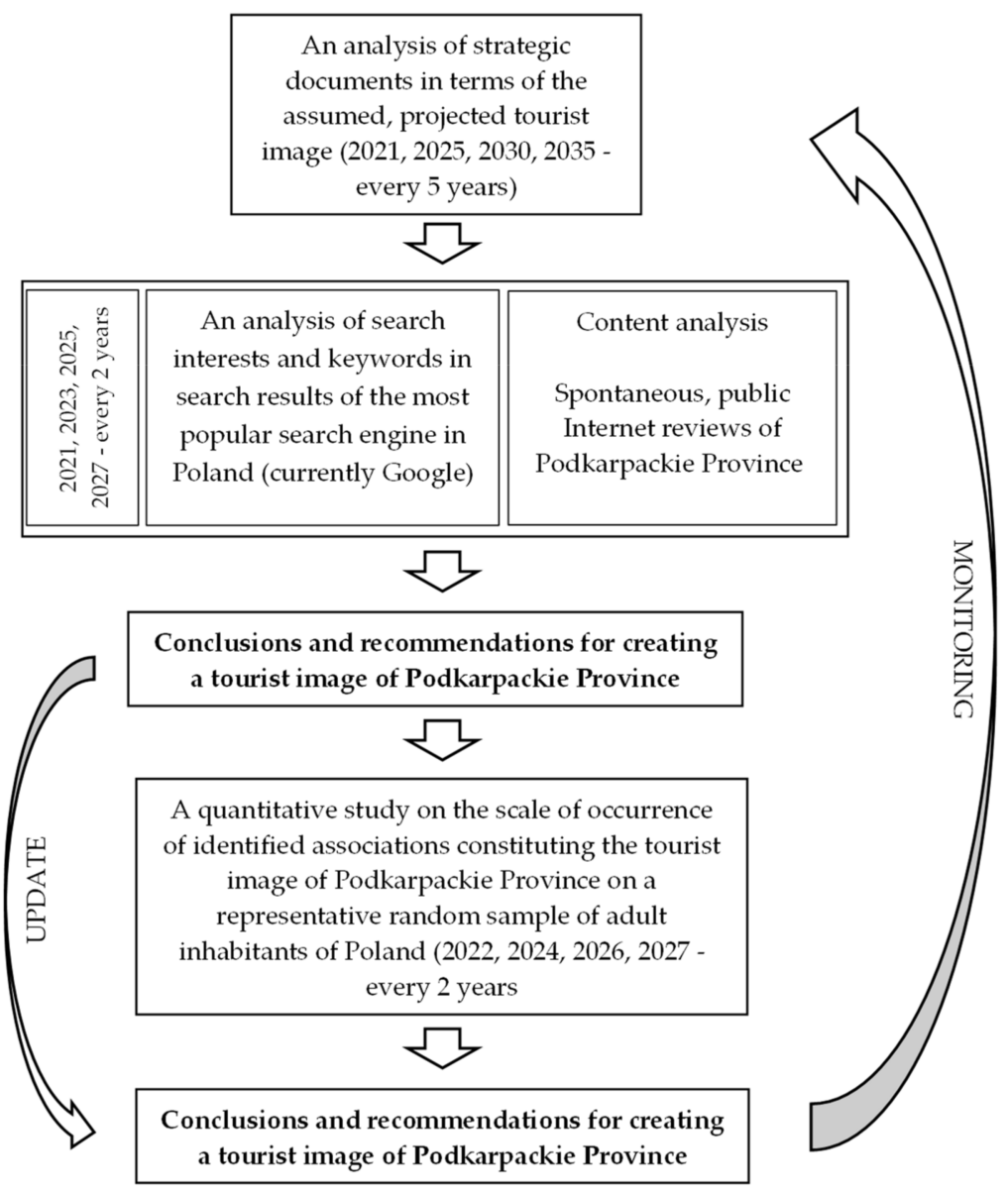

Figure 1. An algorithm of cyclical research on the tourist image of Podkarpackie Province.

The proposed set of methods and techniques results directly from the following assumptions:

- the internet (in particular Google Search), besides direct contacts and relations between relatives and friends, is the main source of information on tourist attractions of Podkarpackie Province;

- Podkarpackie Province is mainly visited by domestic tourists, residents of Polandand in the case of foreign tourists, also by Polish citizens permanently living abroad;

- $\quad$ study of the perceptions of Podkarpackie Province among tourists and one-day visitors who decided to visit the province is conducted within the framework of cyclical research of tourism movement;

- however, tourists and one-day visitors to Podkarpackie Province constitute a small part of the entire tourist market in Poland-so it is crucial to also know the opinions of potential tourists and one-day visitors. After all, communication of the tourist image of Podkarpackie Province is aimed at them, in order to effectively encourage them to visit the region;

- image research should be conducted with basic strategic documents on the province which determine the definition and main activities in the communication of the tourist brand of Podkarpackie Province.

The framework of the institutionalised and managed tourist image of Podkarpackie Province is currently set by two documents adopted and implemented by the Board of Podkarpackie Province. These include:

- a strategy for the development and marketing communication of tourism in Podkarpackie Province for 2020-2025, adopted by Resolution No. 167/3530/20 of 16 June 2020, and 
- revitalisation of the brand strategy of Podkarpackie Province. The guidelines for the implementation of the brand strategy in 2020-2025 entitled 'Podkarpackie. Open Space for the Resourceful", adopted by Resolution No. 199/4072/20 of 15 September 2020.

Both documents were thoroughly analysed to clearly define the scope of creation of a tourist brand and image of Podkarpackie Province. The analysis was conducted with Atlas.ti software, which provided unambiguous quantitative indications of the conceptual apparatus used by the two independent teams of experts responsible for the preparation of the above documents.

Then, the fragments that directly related to these concepts were analysed thanks to the quantitative identification of the basic concepts related to a brand and image. In this way, extensive and complex documents as a whole, where the complex narrative could make it difficult to interpret the authors' intentions, were avoided. In addition, the focus was placed on the conceptual apparatus and the reconstruction of the meanings ascribed to them, which led to the construction of an argumentative model of the tourist image of Podkarpackie Province in an objective, reproducible and transparent manner.

On the other hand, spontaneously generated Internet content concerning the tourist image of Podkarpackie Province defined in this study is characterised by a longer period of impact - it can be searched for a longer time and may be treated by potential tourists and one-day visitors as a source of information about Podkarpackie Province even if it was published a few or several years back. The selection should, therefore, take into account:

- a high position in Google Search (it is the most popular internet search engine in Poland) within a given keyword (but limited to 50 search results) - in incognito mode so that the algorithms supporting search preferences do not amplify the results obtained for previously searched keywords,

- the scale of the potential impact on reviews of Podkarpackie Province, if verifiable, measured by:

- the number of citations and shares,

- the number of social reactions,

- $\quad$ the number of comments under the main thread under analysis,

- the type of source where the content was posted,

- the type of analysed content itself (including additional elements that may strengthen the message),

- finally, the time of publication of the analysed content (published within the previous 5 years, assuming that the earlier elements do not indicate that the content should be yet included despite its older publication date).

Finally, the aforementioned verification and sampling of the currently popularised tourist image of Podkarpackie Province was conducted via CAWI (Computer-Assisted Web Interview). The electronic questionnaire can and should be provided through an internet panel. The basic advantage of the internet panel is the quality of the database of respondents, who are usually selected in a strictly defined way, electronically and traditionally, by phone and during face-to-face interviews. The panel owner-a research company-usually verifies the participants and acquires a range of key information about each respondent. Moreover, it actively manages such a panel, i.e., when respondents withdraw (random cases, death), it attracts more audience; however, it also motivates respondents to participate in the questionnaire, significantly increasing the response rate. Usually, internet panels are constructed in such a way as to reflect the adult population of Poland as closely as possible, thanks to which the obtained results are characterised by a high level of representativeness (fully calculable). Internet panels, counting active respondents in the tens of thousands, are currently used by all major research agencies in Poland. 
From the point of view of the assumptions made above, the use of an electronic questionnaire provided in the internet panel has another key advantage-it is a response to the already mentioned results of the research on tourism in Podkarpackie Province, where the internet is the most popular source of information about Podkarpackie Province. In 2020,90.4\% of households in Poland already had access to the internet [59]. Taking these two factors into account, research where the Internet panel is used is most appropriate in a population which uses the internet as the most popular source of information on the tourist values of the chosen destinations.

The final step in developing the methodology for cyclical research of the tourist image of Podkarpackie Province was to coordinate the various elements in time.

Due to the timeframe for strategic documents (7-10 years on average), it is not advisable to conduct research more frequently than every 5 years. This is because the conclusions of the qualitative and quantitative analysis may possibly lead to the update of strategic assumptions, but with a time horizon not shorter than 5 years - two cycles of quantitative and qualitative research. Once every two years, the internet content on the values of Podkarpackie Province is analysed. On the basis of the obtained results, a spontaneous, natural and individually created tourist image of Podkarpackie Province is reconstructed. This image is then verified in terms of its prevalence and possible statistically significant socio-demographic factors in quantitative research on representative samples of the adult Polish population. Both the two iterations of qualitative research and the two iterations of quantitative research enable the formulation of conclusions for the on-going evaluation of strategic documents and possible updates or modifications to them.

Thanks to this solution, two main assumptions constituting the foundations of the adopted methodology are met-on the one hand, strategic documents setting out the main directions and methods of action to create the image of tourism in Podkarpackie Province are subject to multidimensional monitoring, and the effectiveness of such actions is evaluated; on the other hand, qualitative research provides hypotheses for quantitative empirical verification. Therefore, the teams responsible for updating strategic documents will have reliable information on the effectiveness of the designed activities.

An attractive and heterogeneous tourist image may determine the strength and competitive advantage of the region. However, the creation of such an image requires the consideration and analysis of many factors which will provide the basis for the development of an effective research methodology for its measurement. Effective methodology identifies and tracks changes in the preferences and assessment of tourists because the image of the region is not static. Therefore, the authors of this publication have proposed an innovative solution for the methodology of cyclical research into the tourist image of Podkarpackie Province, extending and supplementing the existing knowledge in this area.

1. Research on the tourist image has never been conducted in a comprehensive and cyclical manner in Podkarpackie Province. The idea to conduct this type of research in a longer time perspective seems very interesting. It will make it possible to observe the changes taking place and correct activities related to the promotion of the region on an ongoing basis.

2. Key information is essential for the effective implementation of tourist policy and promotional activities in Podkarpackie Province and any other tourist region. The most important are the volume and structure of tourism, as well as the tourist image. Data on the volume of tourist traffic are collected by the Central Statistical Office, and knowledge on the structure of tourism is provided by regional tourist research. The image research is the last of the three main elements which has been missing so far in order to successfully conduct this type of activity.

3. The methodology proposed by the authors is also a response to the scale of the challenge to research the tourist image of the entire administrative region. The most common research into tourist destinations is so much simpler, as it is easier to construct and manage the tourist brand of one location. The province is a heterogeneous area, 
consisting of many different sub-regions and localities with diversified values. The strategy of Podkarpackie Province assumes as many as five image sub-regions.

4. The solutions the authors know and present in the article refer to the research of tourists in a given tourist destination. In other words, the tourist image is studied among those who, in a sense, liked it, or at least did not have their decision to visit a given place negatively influenced by the image. However, a question arises about all those who are not convinced to visit the place by the exhibited tourist values. The presented methodology uses online data generated spontaneously and nationwide quantitative research on representative samples. This is an attempt to capture the perspective of not only those who came to visit Podkarpackie Province, but also those who, for various reasons, did not want to come there.

5. For the first time in Podkarpackie Province, cyclical image research was planned in order to formulate conclusions and recommendations not only for short-term promotional activities, but also to attempt to construct a medium- and long-term image strategy. In order to do this, it is necessary to have data developed in as consistent a methodology as possible, which would allow comparisons over longer periods of time.

6. A long-term research project which assumes cyclicality is still rare, especially in mixedmethodology research. In this respect, the authors are aware of their participation in a special undertaking and look forward with genuine enthusiasm to further results and outcomes - not only in terms of the results of the analysis, but also, precisely, in the context of the practicality of the designed process of data collection.

\section{Results of the First Stage of Cyclical Research on the Tourist Image of the Region and a Discussion-A Qualitative Perspective}

\subsection{An Assumed Image-An Analysis of Strategic Documents}

Firstly, in accordance with the adopted algorithm, the analysis included the image of Podkarpackie Province assumed by the authors of both strategic documents, which had been adopted by the Province Board as the binding guidelines in the policy of the creation and management of the region's image. All the words occurring in both documents were counted with Atlas.ti software, then grouped according to the area and meaning, to be finally assigned to abstract 'keywords.' Coding, i.e., assigning a given word from the strategy document to an abstract 'keyword', was performed independently for both documents, but according to one common list which was expanded and supplemented, as necessary, if additional elements or associations appeared in either document. In this way, the conceptual apparatus had been created, which was used by the two independent teams of experts responsible for preparing these documents-169 'keywords' categorised into 11 categories including 'features,' 'purpose of the trip,' 'interests,' 'attractions,' 'natural values,' 'environment,' 'emotions,' 'personalities,' 'types of tourism' and 'others.'

In the case of 'A Strategy for the Development and Marketing Communication of Tourism in Podkarpackie Province for 2020-2025,' the core of the most important associations with Podkarpackie Province is a sequence of keywords ranging from 'development' through 'hiking,' 'cuisine,' 'uniqueness,' 'exploration,' 'attractions,' 'locality' to 'Bieszczady.' The other keywords appear less frequently in the document. Thus, if the image of Podkarpackie Province were to be built solely on the basis of this list, it would be a developing province (dynamism) where you can enjoy hiking as well as try unique cuisine, and explore the attractions of small local communities mainly located in the Bieszczady. In the second place, there are additional keywords such as 'activity,' 'impressions,' 'involvement,' 'sub-regions,' 'quality,' 'accommodation,' 'past,' 'bicycle' and 'hospitality.' Thus, the tourist image of Podkarpackie Province is complemented by the possibility of active leisure, filled with impressions which vary within the province. Tourist traffic accumulates in specific sub-regions which are the starting point for travelling. The offer is of an appropriate quality and the accommodation capacity is high and varied, so tourists can discover the past, also by bike, but each time enjoying the hospitality of the local people. However, elements 
connected with nature come third and so do details of the past ('heritage' and 'nobility'much more often than 'folklore' and 'museums') and impressions ('adventure,' 'nature,' 'landscape,' 'mountains,' 'health' and 'themes'). Another important component of the third group of the tourist image of Podkarpackie Province is 'oenotourism', to which the authors of the analysed strategy referred 61 times in various ways. In the document, Rzeszów is one of the cities most often associated with Podkarpackie Province. Only Zdzisław Beksiński, a painter associated with Sanok, 24 February 1929-21 February 2005, and Ignacy Łukasiewicz, an oil industry pioneer, 8 March 1822-7 January 1882, were included among the brand ambassadors (magnificent people).

In turn, 'Revitalisation of the Brand Strategy of Podkarpackie Province' puts the emphasis first on 'resourcefulness,' which, moreover, correlates with the proposed new slogan: 'Podkarpackie. Open Space for the Resourceful.' However, the core is, additionally, constituted with 'impressions,' ‘values, ' 'uniqueness, ' 'emotions,' ‘development,' ‘economy,' 'culture' and 'exploration.' Podkarpackie Province is, therefore, for resourceful people, open to unique experiences and values which provide special emotions. It is a province characterised by development thanks to its economy, but also famous for its unique culture. All this can be explored. In second place come the following: 'people,' 'nature,' 'creativity,' 'pragmatism,' 'story' and 'entrepreneurship.' So, on the one hand, there is a special story about the nature and inhabitants of the region, but with a special emphasis on the creativity, entrepreneurship and pragmatism of the latter. It therefore comes as no surprise that Łukasiewicz appears as many as 22 times in the analysed document, while Rzeszów is the most frequently mentioned place associated with Podkarpackie Province. All the other keywords only specify these two main groups of images associated with the province. This document is more general in nature, as it refers not only to tourist aspects, but also to the economic and social aspects of the province, providing varied guidelines for image creation depending on the target audience - it will differ for tourists, businesspeople or residents. Nevertheless, both strategic documents relate directly to the province brand and image creation, including tourism. Therefore, if we try to compare them, despite obvious differences in the way they describe Podkarpackie Province, we can obtain a set of keywords, which, in the intention of the Province Board, should be the main focus of the tourist image of Podkarpackie Province. Thus, it is a province which is primarily focused on developing (Figure 2).

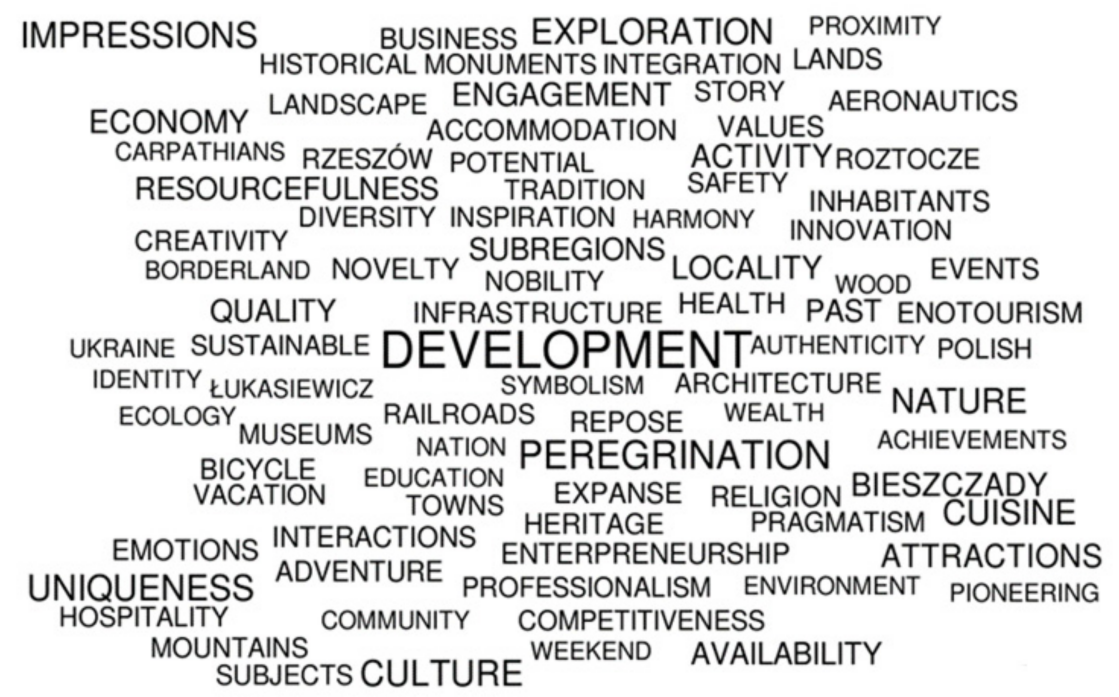

Figure 2. Word cloud of keywords identified in both strategic documents.

It is associated with dynamism, change, freshness and openness. It is certainly unique, providing special experiences-mainly related to the culture of this area. The whole region can be explored mainly while hiking. Its uniqueness is mainly manifested in the varied 
cuisine. Tourists also explore other attractions, not necessarily precisely indicated-it is rather an image-related issue. Locality and the Bieszczady are strongly interrelated. Activity, involvement and values are not without significance in the main image. The whole image is closed with 'the past.' Nature, wildlife and inhabitants come third. These carry the main image elements. This category of keywords also includes 'bicycle' —another way to actively explore the varied area of the province.

\subsection{A Spontaneous Image-An Analysis of Internet Reviews}

The analysis of internet sources showed, first of all, that specific attractions are crucial for the perception of tourist values of Podkarpackie Province. Generally, on the basis of Google Trends and Ubersuggest results, people looking for inspiration and suggestions on a trip to Podkarpackie Province focus on the following combinations of words: 'podkarpackie' or 'podkarpacie', with general words 'tourism' or 'attractions,' possibly 'lakes,' 'trails' or 'for children.' The names of specific places are equally important. In other words, for an average tourist, Podkarpackie Province is not a homogenous area. In fact, tourists do not perceive the region in terms of administrative divisions. Attention is placed on specific expectations and needs - then the search engine query returns results for relevant places located in Podkarpackie Province, or on specific places-then the search engine query returns potential attractions located there.

The analysis included search results with at least 999 reviews which started with an evaluation and ended with a more detailed opinion-that is, a total of 48 out of 326 identified tourist attractions. The number of reviews and the scale of evaluations increase the probability that precisely such attractions or locations will be displayed in the first search results, according to the scheme indicated above. Therefore, they are crucial for the final reception of the tourist attractions of Podkarpackie Province, especially since, as already mentioned, it is the internet that is one of the main sources of information about the region.

On the basis of the previously analysed strategic documents, Podkarpackie Province was divided into five tourist sub-regions, each offering different opportunities for travelling. Therefore, these 48 tourist attractions were assigned to individual sub-regions along with the number of reviews they received (Figure 3).

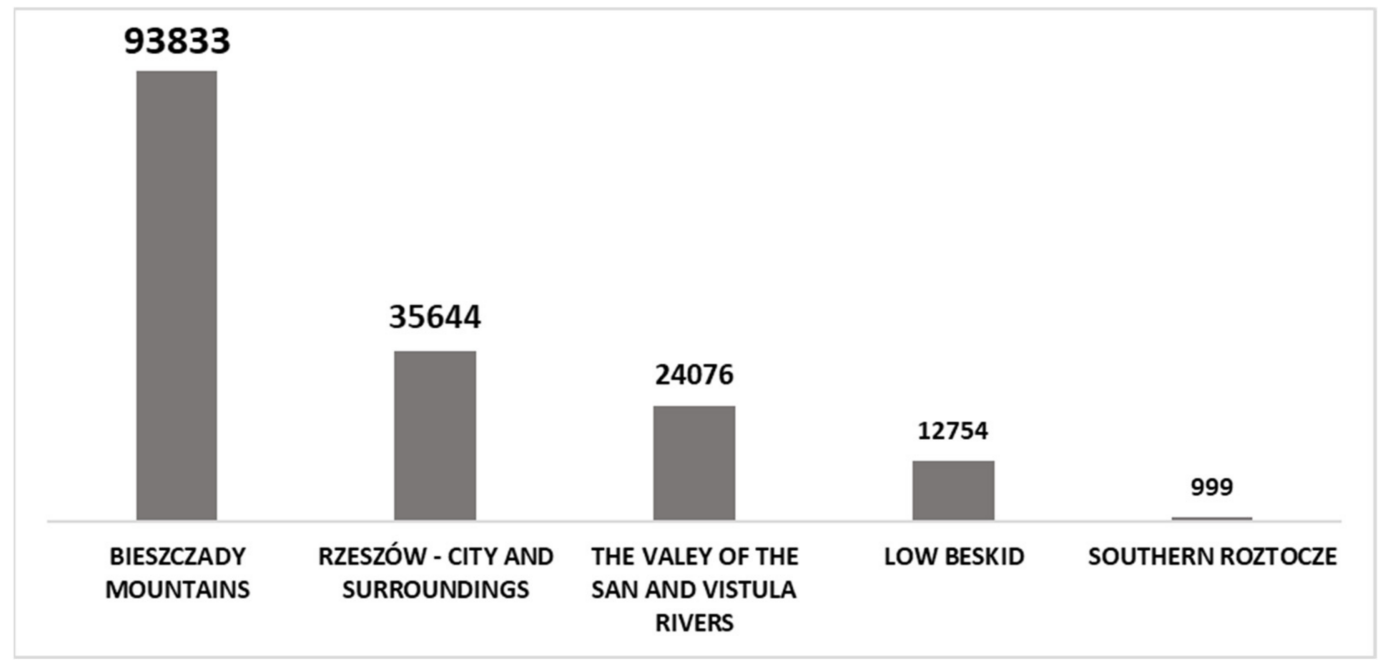

Figure 3. The sub-regions of Podkarpackie Province by the number of reviews of attractions (with at least 999 reviews on Google Maps).

The Bieszczady Mountains and Rzeszów, the city and its surroundings, are the two sub-regions characterised by the highest share of tourist traffic in Podkarpackie Province. Most of the tourist attractions particularly associated with Podkarpackie province are also concentrated here. Thus, a feedback mechanism is revealed, when widely recognised 
places attract the attention of a significant number of tourists who, in turn, publish a correspondingly larger number of reviews on the internet; this, in turn, increases the recognition of these places.

A total of 960 reviews were aggregated for the above 48 attractions-longer or shorter text evaluations with a 'star' rating-including 20 for each attraction from the last 12 months. In these online reviews, it is difficult to find explicit terms and associations to be considered crucial by the experts who developed the image strategies of Podkarpackie Province, although the province perceived through the prism of the Bieszczady Mountains provides its visitors with attractions and experiences. It should be added, however, that specific needs come first—curiosity or rest (Table 2).

Table 2. Keywords in strategic documents developed for the province and from internet sources.

\begin{tabular}{|c|c|c|c|c|c|}
\hline \multicolumn{2}{|c|}{$\begin{array}{l}\text { Strategy for the Development and } \\
\text { Marketing Communication of Tourism } \\
\text { in Podkarpackie Province for 2020-2025 }\end{array}$} & \multicolumn{2}{|c|}{$\begin{array}{l}\text { Revitalization of Brand Strategy of } \\
\text { Podkarpackie Province. The Guidelines } \\
\text { for the Implementation of Brand Strategy } \\
\text { in 2020-2025 Entitled "Podkarpackie. Open } \\
\text { Space for the Resourceful" }\end{array}$} & \multirow{2}{*}{$\begin{array}{c}\text { A Spontaneous Tourist } \\
\text { Image of Podkarpackie } \\
\text { Province-The Internet } \\
\text { Sources } \\
\text { Keyword }\end{array}$} & \multirow[b]{2}{*}{$\%$} \\
\hline Keyword & $\%$ & Keyword & $\%$ & & \\
\hline development & 9.01 & resourcefulness & 6.87 & curiosity & 13.86 \\
\hline hiking & 3.95 & impressions & 6.29 & cities & 6.98 \\
\hline cuisine & 3.50 & values & 5.38 & attractions & 6.34 \\
\hline uniqueness & 2.92 & uniqueness & 5.05 & impressions & 4.89 \\
\hline exploration & 2.82 & emotions & 4.86 & climate & 3.99 \\
\hline culture & 2.82 & development & 4.60 & water & 3.53 \\
\hline attractions & 2.64 & economics & 4.15 & museums & 3.35 \\
\hline locality & 2.55 & culture & 3.56 & Bieszczady & 3.26 \\
\hline Bieszczady & 2.36 & exploration & 3.44 & rest & 3.08 \\
\hline activity & 2.24 & citizens & 2.85 & mountains & 2.63 \\
\hline impressions & 2.13 & nature & 2.46 & Przemyśl & 2.36 \\
\hline engagement & 2.10 & creativity & 2.33 & open-air museum & 2.36 \\
\hline subregions & 2.03 & pragmatism & 2.07 & availability & 2.08 \\
\hline quality & 1.99 & story & 1.88 & differentiation & 2.08 \\
\hline
\end{tabular}

The most important thing, however, is that for an average tourist, Podkarpackie Province 'is transparent' - it is not an area for searching for specific experiences or emotions. While in strategic documents, it is assumed that Podkarpackie Province is a specific common ground for certain image elements, the starting points for tourists are specific needs and expectations, often very specific places. This is what they look for and, then, what they assign their emotions and assessments to.

Coding the opinions aggregated from internet sources leads to a different list of priorities for tourists, through the prism of which they perceive the attractions (which just so happen not to be important for them) located in Podkarpackie Province. The chart below (Figure 4) presents the distribution of elements according to the positive reviews, but if the overall number of reviews were taken into account, 'infrastructure' would come first as the key element in the assessment. 


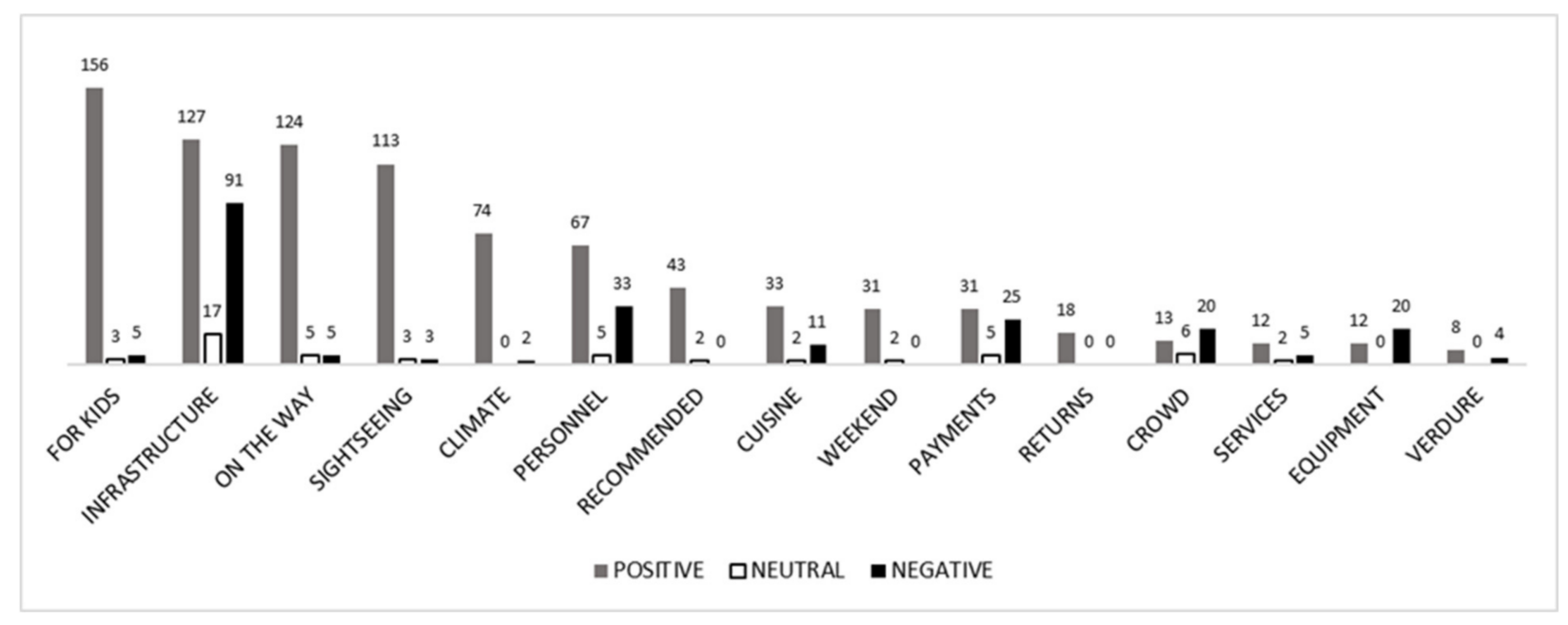

Figure 4. Frequency distribution of positive, neutral and negative reviews by topic in spontaneously generated internet content about tourist attractions of Podkarpackie Province.

\section{Conclusions}

So far, no studies related to the methodology of the tourist image of the region have attempted to integrate the assumptions and knowledge from strategic documents prepared by experts with the widely understood opinions and assessments from the general public. Therefore, in the proposed methodology, the algorithm of particular stages of activities reflects the outlined dichotomy-the institutionalised and strategy-managed image versus spontaneous, impulsive individual opinions, with the regular evaluation of currently popular beliefs about the tourist assets of Podkarpackie Province.

The obtained results indicate that potential tourists find online information about tourist attractions of Podkarpackie Province deviating from the planned tourist image. First of all, they look for opinions and tips on specific tourist attractions. Podkarpackie Province is not a point of reference at all-it is 'transparent.' It should be remembered that the starting point was the results of the study of tourist traffic in 2020, which clearly show that the internet is an important source of information about tourist attractions. However, specific destinations appear to be crucial, including the Bieszczady, specific towns or even 'attractions for children' or 'on the way.'

However, in fact, these particular attractions are located in sub-regions, although the Bieszczady sub-region and Rzeszów, the city and its surroundings definitely dominate. Therefore, it is worth considering this fact and treating the most important locations or attractions, gathering the greatest number of reviews, as 'workhorses' for strategically important sub-regions. The authors of the strategy actually took into account the fact that the area of Podkarpackie Province is not homogenous in terms of its tourist potential, and proposed a division into five sub-regions including the Bieszczady, Rzeszów-the city and its surroundings, the San and Vistula valleys, the Low Beskids and the Southern Roztocze. Therefore, the basic conclusion is that an effort should be made to develop five slightly different visions of the tourist assets of Podkarpackie Province depending on the given sub-region.

Moreover, in the perception of average, potential tourists, the Low Beskids and the Southern Roztocze are practically unnoticeable and clearly 'lose' with the Bieszczady, which are most associated with Podkarpackie Province. Therefore, there is a clear need to put more emphasis on the promotion of areas that are equally interesting as tourist destinations, but still less recognisable and less developed in this respect.

Of course, it should be remembered that the presented results relate to the generated content; that is, on the one hand, what a potential tourist encounters and, on the other hand, what image is created in strategic documents. Therefore, the next step is to verify how and to what extent potential tourists perceive the tourist assets of Podkarpackie Province; 
i.e., it is necessary to conduct quantitative research on a representative sample of adult residents of Poland - the research on tourism and the data of the Central Statistical Office unambiguously indicate that $85-90 \%$ of tourists to Podkarpackie Province are domestic.

In the opinion of the authors, the methodology of cyclical research into the tourist image of Podkarpackie Province presented in the article is a solution which met the assumed objectives. Both the methodology and selected research results constitute an empirical argument for the necessity of cyclical research on the tourist image of Podkarpackie Province in order to provide targeted guidelines for sustainable tourist development in the region.

The authors also notice elements that can be corrected. On the basis of the results of a qualitative study of the spontaneously generated internet content on the tourist assets of Podkarpackie Province, minor modifications to the quantitative tool were proposed. These mainly concerned the response options.

However, it should be noted that the indicated methodology should generally be flexible. The presented tool may, or even should be, modified in relation to the changing market of tourist attractions and services or based on the demand for specific information from the Podkarpackie Regional Tourist Organization. The advantages of Podkarpackie Province are its unique natural and cultural values. They attract tourists from all over Poland and the tourist image of the region relies on them. From an economic point of view, the tourist industry expects a large number of tourists to generate profits. However, there is a need for a wise and rational vision of the region's development, which will give the possibility of reaping economic benefits from tourism, while preserving its most valuable assets. Image research is one of the elements which facilitates such activities in accordance with the principles of sustainable development.

Comprehensive image research consists of qualitative and quantitative modules. Only the combination of both will allow for a holistic view of the image of the region. However, in the opinion of the employees of the Podkarpackie Regional Tourist Organisation, the results already obtained during the qualitative research are interesting and important for the promotion of the region, and the preliminary reading of the Report inspires ideas for many activities.

This type of research project, spread over 5 years, including iterations of qualitative and quantitative rounds, is extremely complex. The authors have not encountered a similar proposal in the literature. The final substantive and practical assessment will only be possible after the conclusion of at least the first five-year period. However, the results of the qualitative research, briefly presented in this article, are optimistic. They provide arguments for further continuation of the project. The conclusions from the analysis of the widely available internet opinions of potential tourists and one-day visitors already show that the assumptions presented in the strategic documents do not necessarily correspond to the realities of individual decision-making processes. Thus, the directions of promotional campaigns need to be corrected. This year's quantitative research will provide further information on the scale of occurrence of particular associations and evaluation schemes in particular socio-demographic categories.

Author Contributions: Conceptualization, B.J.G.-K., M.S. and K.S.; methodology, B.J.G.-K., M.S. and K.S.; formal analysis, M.S.; resources, B.J.G.-K.; data curation, M.S.; writing-original draft preparation, B.J.G.-K., M.S. and K.S. All authors have read and agreed to the published version of the manuscript.

Funding: This research was funded by Podkarpackie Regional Tourism Board within Podkarpackie Tourist Barometer with the support of Podkarpackie Province. The paper was financed by the University of Rzeszow.

Institutional Review Board Statement: Not applicable.

Informed Consent Statement: Informal consent was obtained from all key informants involved in the study. 
Data Availability Statement: The data presented in this study are available on request from the corresponding author.

Acknowledgments: The authors are grateful to the anonymous reviewers, who have provided constructive ideas and insightful comments for this study.

Conflicts of Interest: The authors declare no conflict of interest.

\section{References}

1. Szpara, K.; Gierczak-Korzeniowska, B.; Stopa, M. Metodologia Cyklicznych Badań Ruchu Turystycznego w Województwie Podkarpackim; Podkarpacka Regionalna Organizacja Turystyczna: Rzeszów, Poland, 2020.

2. Szpara, K.; Gierczak-Korzeniowska, B.; Stopa, M. Raport z Badań Ruchu Turystycznego w Województwie Podkarpackim; Podkarpacka Regionalna Organizacja Turystyczna: Rzeszów, Poland, 2020.

3. Szpara, K.; Gierczak-Korzeniowska, B.; Stopa, M. Raport z Badań Ruchu Turystycznego w Województwie Podkarpackim; Podkarpacka Regionalna Organizacja Turystyczna: Rzeszów, Poland, 2021.

4. $\quad$ Szpara, K.; Gierczak-Korzeniowska, B.; Stopa, M. Metodologia Cyklicznych Badań Wizerunku Turystycznego Województwa Podkarpackiego; Podkarpacka Regionalna Organizacja Turystyczna: Rzeszów, Poland, 2021.

5. Stopa, M.; Gierczak-Korzeniowska, B.; Szpara, K. Raport z Badań Wizerunku Turystycznego Województwa Podkarpackiego; Podkarpacka Regionalna Organizacja Turystyczna: Rzeszów, Poland, 2021.

6. Kock, F.; Josiassen, A.; Assaf, A.G. Advancing destination image: The destination content model. Ann. Tour. Res. 2016, 61, 28-44. [CrossRef]

7. Zhang, H.; Cho, T.; Wang, H.; Zhang, H.; Cho, T.; Wang, H. The Impact of a Terminal High Altitude Area Defense Incident on Tourism Risk Perception and Attitude Change of Chinese Tourists Traveling to South Korea. Sustainability 2020, 12, 7. [CrossRef]

8. Nazir, M.U.; Yasin, I.; Tat, H.H. Destination image's mediating role between perceived risks, perceived constraints, and behavioral intention. Heliyon 2021, 7, e07613. [CrossRef] [PubMed]

9. Baloglu, S.; McCleary, K.W. A model of destination image formation. Ann. Tour. Res. 1999, 26, 868-897. [CrossRef]

10. Chon, K.-S. The role of destination image in tourism: A review and discussion. Tour. Rev. 1990, 45, 2-9. [CrossRef]

11. Jenkins, H.O. Understanding and Measuring Tourist Destination Images. Int. J. Tour. Res. 1999, 1, 1-15. [CrossRef]

12. Agapito, D.; do Valle, P.O.; Mendes, J.C. The cognitive-affective-conative model of destination image: A confirmatory analysis. J. Travel Tour. Mark. 2013, 30, 471-481. [CrossRef]

13. Li, R.; Wang, H.; Zhang, H.; Li, R.; Wang, H.; Zhang, H. Chinese Tourists' Perception of the Tourism Image of North Korea Based on Text Data from Tourism Websites. Sustainability 2021, 13, 12205. [CrossRef]

14. Wiesender, S. Skuteczne Zarzadzanie Reputacja i Spójny Image; BestPress Wyd. Sp. z o. o.: Warszawa, Poland, 2008 ; p. 35.

15. Mikołajczyk, A. Pierwszy Raport o Stanie Marketingu Miejsc w Regionach i Miastach Polski, Częśc 2.—Marketing Wizerunku; Wyd. Brief for Poland: Warszawa, Poland, 2007.

16. Kotler, P.; Haider, D.H.; Rein, I. Marketing Places: Attracting Investments, Industry, and Tourism to Cities, States, and Nations; The Free Press: New York, NY, USA, 1993.

17. Kotler, P.; Gertner, D. Country as Brand, Product and Beyond: A Place Marketing and Brand Management Perspective. In Destination Branding: Creating the Unique Destination Proposition, 2nd ed.; Morgan, N., Pritchard, A., Pride, R., Eds.; ButterworthHeinemann: Oxford, UK, 2004; pp. 40-56.

18. Reynolds, W.H. The role of the consumer in image building. Calif. Manag. Rev. 1965, 7, 69-76. [CrossRef]

19. Zalech, M. Wizerunek miasta (miejsca) jako czynnik rozwoju turystyki. In Przyroda a turystyka we wschodniej Polsce; Żabka, M., Kowalski, R., Eds.; Wydawnictwo Akademii Podlaskiej: Siedlce, Poland, 2007; pp. 402-415.

20. Papadimitriou, D.; Apostolopoulou, A.; Kaplanidou, K. Destination personality, affective image, and behavioral intentions in domestic urban tourism. J. Travel Res. 2015, 54, 302-315. [CrossRef]

21. Gunn, C. Vacationscape: Designing Tourist Regions; Taylor and Francis: Washington, DC, USA, 1972; p. 238.

22. Mayo, E.J. Regional images and regional travel development. In Proceedings of the Travel and Tourism Research Association Fourth Annual Conference, Salt Lake City, UT, USA, 8-11 September 1973; pp. 211-217.

23. Hunt, J. Image as a factor in tourism development. J. Travel Res. 1975, 1, 1-7. [CrossRef]

24. Kim, H.; Richardson, S.L. Motion picture impacts on destination images. Ann. Tour. Res. 2003, 30, 216-237. [CrossRef]

25. Grosspietsch, M. Perceived and projected images of Rwanda: Visitor and international tour operator perspectives. Tour. Manag. 2006, 27, 225-234. [CrossRef]

26. Echtner, C.M.; Ritchie, J.R.B. The Measurement of Destination Image: An Empirical Assessment. J. Travel Res. 1993, 31, 3-13. [CrossRef]

27. Embacher, J.; Buttle, F. A repertory Grid Analysis of Australia's Image as a Summer Vacation Destination. J. Travel Res. 1989, 28, 3-23. [CrossRef]

28. Govers, R.; Go, F.M. Culture identities constructed, images: The 3-gap Tourism Destination Identity and Image Creation Model. Tour. Interdiscip. J. 2004, 52, 165-183.

29. Sun, W.; Tang, S.; Liu, F. Examining Perceived and Projected Destination Image: A Social Media Content Analysis. Sustainability 2021, 13, 3354. [CrossRef] 
30. Baloglu, S.; Brinberg, D. Affective image of tourism destinations. J. Travel Res. 1997, 35, 11-15. [CrossRef]

31. Bigne, J.E.; Sanchez, M.I.; Sanchez, J. Tourist image, evaluation variables and after purchase behaviour: Inter-relationship. Tour. Manag. 2001, 22, 607-616. [CrossRef]

32. Alcañiz, E.B.; García, I.S.; Blas, S.S. The functional-psychological continuum in the cognitive image of a destination: A confirmatory analysis. Tour. Manag. 2009, 30, 715-723. [CrossRef]

33. Hallmann, K. Perceived destination image: An image model for a winter sports destination and its effect on intention to revisit. J. Travel Res. 2015, 54, 94-106. [CrossRef]

34. Farmaki, A. A comparison of the projected and the perceived image of Cyprus. Tour. Int. Multidiscip. J. Tour. 2012, 7, 95-119.

35. Stern, E.; Krakover, S. The formation of a composite urban image. Geogr. Anal. 1993, 25, 130-246. [CrossRef]

36. Bosque, I.; Martin, H. Tourist Satisfaction: A Cognitive-Affective Model. Ann. Tour. Res. 2008, 35, 551-573. [CrossRef]

37. Stepchenkova, S.; Mills, J. Destination Image: A meta-Analysis of 2000-2007 Research. J. Hosp. Mark. Manag. 2010, 19, 575-606. [CrossRef]

38. Konecnik, M.; Gartner, W. Customer-Based Brand Equity for a Destination. Ann. Tour. Res. 2007, 34, 400-421. [CrossRef]

39. MacInnis, D.J.; Price, L.L. The role of imagery in information processing: Review and extension. J. Consum. Res. 1987, 13, 473-491. [CrossRef]

40. Goodrich, N. A New Approach to Image Analysis through Multidimensional Scaling. J. Travel Res. 1978, 16, 3-7. [CrossRef]

41. Gali, N.; Donaire, J.A. The social construction of the image of Girona: A methodological approach. Tour. Manag. 2005, 26, 777-785. [CrossRef]

42. Virdee, I. Tourism Destination Image Analysis: Integrating a Visual Methodology. e-Rev. Tour. Res. (eRTR) 2019, 16, 434-456.

43. McKercher, B. Towards a taxonomy of tourism products. Tour. Manag. 2016, 54, 196-208. [CrossRef]

44. Echtner, C.M.; Ritchie, J.R.B. The Meaning and Measurement of Destination Image. J. Tour. Stud. 2003, 14, 37-48.

45. Shin, J. Tourism image on KOREA and JAPAN. Int. J. Tour. Hosp. Res. 1995, 5, 75-86.

46. Dwivedi, M. Online destination image of India: A consumer based perspective. Int. J. Contemp. Hosp. Manag. 2009, 21, 226-232. [CrossRef]

47. Zhou, L. Online rural destination images: Tourism and rurality. J. Destin. Mark. Manag. 2014, 3, 227-240. [CrossRef]

48. Marine-Roig, E.; Anton Clavé, S. Destination image gaps between official tourism websites and user-generated content. In Information and Communication Technologies in Tourism 2016; Springer: Cham, Switzerland, 2016; pp. 253-265. [CrossRef]

49. Meneghello, S.; Montaguti, F. Travel writings and destination image. In Destination Marketing: An International Perspective; Kozak, M., Kozak, N., Eds.; Routledge: New York, NY, USA, 2016; pp. 39-48.

50. Marine-Roig, E. Destination Image Analytics through Traveller-Generated Content. Sustainability 2019, 11, 3392. [CrossRef]

51. Choi, S.; Lehto, X.Y.; Morrison, A.M. Destination image representation on the web: Content analysis of Macau travel related websites. Tour. Manag. 2007, 28, 118-129. [CrossRef]

52. Marine-Roig, E.; Ferrer-Rosell, B. Measuring the gap between projected and perceived destination images of Catalonia using compositional analysis. Tour. Manag. 2018, 68, 236-249. [CrossRef]

53. Stepchenkova, S.; Zhan, F. Visual destination images of Peru: Comparative content analysis of DMO and user-generated photography. Tour. Manag. 2013, 36, 590-601. [CrossRef]

54. Melo, H.M.; Moniz, A.I.; Silva, F.J.F.; da Graça Batista, M. Tourist Destination image and consumer behaviour: The case of The Azores. J. Spat. Organ. Dyn. 2017, 5, 73-82.

55. Zahra, I. Destination image and tourism: A case study of Bangladesh. Eur. J. Bus. Manag. 2012, 4, 18-28.

56. Marinao-Artigas, E.; Barajas-Portas, K. A Cross-Destination Analysis of Country Image: A Key Factor of Tourism Marketing. Sustainability 2021, 13, 9529. [CrossRef]

57. Figiel, A. Wizerunek kraju i przedsiębiorstwa na rynkach międzynarodowych—Wzajemne relacje. Zesz. Nauk. Uniw. Szczecińskiego 2010, 56, 101-112.

58. Kotylak, S. Oddziaływanie mediów na kreowanie marki i wizerunku regionu. Zesz. Nauk. Uniw. Szczecińskiego 2010, 56, 127-139.

59. Społeczeństwo Informacyjne w Polsce; Główny Urząd Statystyczny: Warszawa, Poland, 2020; p. 131. Available online: https: //stat.gov.pl/obszary-tematyczne/nauka-i-technika-spoleczenstwo-informacyjne/spoleczenstwo-informacyjne/spoleczenstwoinformacyjne-w-polsce-w-2020-roku,1,14.html (accessed on 23 November 2021). 